\title{
COMPARISON OF BODY COMPOSITION BETWEEN TWO ELITE WOMEN'S VOLLEYBALL TEAMS
}

\author{
Tomáš Malý, Lucia Malá, František Zahálka, Jiř́i Baláš, Miroslav Čada*
}

\author{
Faculty of Physical Education and Sport, Charles University, Prague, Czech Republic \\ * Faculty of Sports Studies, Masaryk University, Brno, Czech Republic
}

Submitted in July, 1010

BACKGROUND: In sport and in top performance sport in particular, the continuous monitoring of body composition (BC) may regulate the training process, affecting positively athletes' top form. $\mathrm{BC}$ is, therefore, considered to be one of the components of the physical fitness of athletes. Research studies dealing with BC in women volleyball players are often focused on a lower performance level when compared with the submitted study. The problem in the field of results comparison is with the variety in the methodology used in BC assessment.

OBJECTIVE: The objective of our study is to describe the body composition (BC) profile of top performance women volleyball players and verify whether there are differences in the chosen parameters between them. The examined group consists of women volleyball players of two teams which were participants in the European Champions League $(\mathrm{T} 1, \mathrm{n}=12 ; \mathrm{T} 2, \mathrm{n}=9)$.

METHODS: By means of multifrequency bioimpedance analysis, we observed Lean Body Mass (LBM), Fat Mass (FM), Body Cell Mass (BCM), relative BCM (BCMrel), ExtraCellular Mass (ECM) and their mutual ratio (of ECM/ BCM), Cell Quote (CQ), phase angle $(\alpha)$, Basal Metabolic Rate (BMR), Total Body Water (TBW) while making a distinction between ExtraCellular (ECW) and IntraCellular (ICW) Water. One-way ANOVA and Cohen's $d$ were used for the comparison of differences between the monitored teams.

RESULTS: Differences in the examined parameters of body composition between the screened samples were not statistically significant $(p>0.05)$. Effect size revealed moderate differences for other parameters $(\alpha, \mathrm{ECM}, \mathrm{BCM}, \mathrm{ECM} /$ BCM, BMR, FM and CQ). Fat mass percentage in our women players was lower in comparison to values recorded in women players in most other studies. The relatively high values of TBW, LBM and ECM/BCM in women volleyball players of both teams indicate their good performance capacity.

CONCLUSIONS: The body composition profile revealed the appropriate predispositions of the observed players for their performance in volleyball. The measured parameters of BC corresponding to top performance sport are better than in high performance sport or in the general population. Our values of BC in elite women volleyball players can serve as standards for other athletes attempting to achieve international level.

Keywords: Physical fitness, physical conditioning, women, body fat, elite sport.

\section{INTRODUCTION}

Body composition (BC) is considered one of the components of the physical fitness of athletes. In elite sport, the continuous monitoring of $\mathrm{BC}$ may regulate the training process affecting positively the top form of sporters. The issues connected with BC in sport, and in volleyball in particular, have been the subject of monitoring for several years (Dostálová, Riegerová, \& Přidalová, 2007; Fleck, Case, Puhl, \& Van Handle, 1985; Nichols, Sanborn, Bonnick, Gench, \& DiMarco, 1995; Tsunawake, Tahara, Moji, Muraki, Minowa, \& Zukawa, 2003; Bandyopadhyay, 2007; Malá, Malý, Zahálka, \& Bunc, 2010; Malosaouris, Bergeles, Barzouka, Bayios, Nassis, \& Koskolou, 2008; Riegerová \& Ryšavý, 2001; Vařeková, Vařeka, Valenta, Přidalová, \& Burianová, 2006).
Häkkinen (1993) suggested that, in volleyball, as in other sports, technical and tactical skills, anthropometric characteristics and individual physical performances are the most important factors in the success of a team. An excessive amount of adipose tissue is considered an unused mass, because the athlete's body has to repeatedly cope with gravitation during locomotion and jumps (Reilly, 1996) which results in a lowering of performance and an increase of demands on energy during the performance of a particular action. The fat free mass, which includes lean muscle mass and bone mineral mass, is important for the production of speed, strength and power, and for injury prevention (Arden \& Spector, 1997). According to Andreoli et al. (2003), the $\mathrm{BC}$ component record and the measurement of body cell mass (BCM), are the best predictors of muscular ef- 
ficiency and may predict sports performance. Significant differences were found in the amount of fat mass (FM) or somatotype in women players of series A1 and A2 in the Italian league (Gualdi-Russo \& Zaccagni, 2001). Fleck et al. (1985) present differences in FM between Olympic winners and university teams.

Anderson (2010) monitors changes in BC values, over a two year period, of college women volleyball players, while gathering feedback on their dietary intake. Over two seasons, the author did not find any significant differences in fat mass percentage by using such feedback as to women players' dietary intake.

The comparison of results from various studies is complicated by the use of different methods for BC assessment: dual-energy X-ray absorptiometry (Carbuhn, Fernandez, Bragg, Green, \& Crouse, 2010; Nichols et al., 1995) air displacement plethysmography (Anderson, 2010), bioelectrical impedance analysis (Frasson, Diefenthaeler, \& Vaz, 2009; Malá et al., 2010), skinfolds (Almeida \& Soares, 2003; Bayios, Bergeles, Apostoldis, Noutsos, \& Koskolou, 2006; Malosaouris et al., 2008; Melrose, Spaniol, \& Bohling, 2007) and hydrodensitometry (Ferris, Signorile, \& Caruso, 1995; Fleck et al., 1985; Kreger \& Brown, 2008; Tsunawake et al., 2003).

Despite the above-mentioned results of several BC indicators in women volleyball players there is little knowledge about $\mathrm{BC}$ indicators in elite teams (participants in the Champions League, Olympic Games, World Championship, European Championship and winners of prestigious club leagues).

In most cases, studies do not deal more closely with other parameters of $\mathrm{BC}$. The compared performance differences among players are evident.

The objective of our study was to describe the profile of top performance women volleyball players and verify whether there are differences in the chosen parameters of $\mathrm{BC}$ between more and less successful teams in the highest European team league.

\section{METHODS}

\section{Study sample}

The screened sample was composed of two volleyball teams, participants in the CEV (Confédération Européenne de Volleyball) Indesit Champions League 2008-2009. The first team (T1, n = 12) did not pass beyond the basic group and therefore in comparison with the second team $(\mathrm{T} 2, \mathrm{n}=9)$ was less successful, because $\mathrm{T} 2$ took part in the quarterfinal round. Team T1 comes from the Czech Republic and team T2 from the Russian Federation. Basic somatometric characteristics of the examined samples are presented in TABLE 1 . The lower number of players in $\mathrm{T} 2$ was caused by the participation of three players in the national teams of their countries during the measurement.

\section{TABLE 1}

Basic somatometric characteristics of the screened samples - mean (standard deviation)

\begin{tabular}{|c|c|c|c|c|}
\hline Team & $\begin{array}{c}\text { Age } \\
\text { (years) }\end{array}$ & $\begin{array}{c}\text { Body height } \\
(\mathbf{m})\end{array}$ & $\begin{array}{c}\text { Body weight } \\
(\mathbf{k g})\end{array}$ & $\begin{array}{c}\text { BMI } \\
\left(\mathbf{k g . m}^{-2} \text { ) }\right.\end{array}$ \\
\hline $\mathrm{T} 1$ & 24.30 & 182.79 & 72.99 & 22.04 \\
$(\mathrm{n}=12)$ & $(2.67)$ & $(5.61)$ & $(6.34)$ & $(1.80)$ \\
\hline $\mathrm{T} 2$ & 20.78 & 184.22 & 71.22 & 21.02 \\
$(\mathrm{n}=9)$ & $(2.05)$ & $(7.95)$ & $(6.26)$ & $(1.86)$ \\
\hline Total & 22.81 & 183.40 & 72.23 & 21.60 \\
$(\mathrm{n}=21)$ & $(2.98)$ & $(6.56)$ & $(6.21)$ & $(1.85)$ \\
\hline
\end{tabular}

Legend: BMI - Body mass index, T1 - less successful team, T2 more successful team

\section{Assessment of body composition}

The data identifying participants' $\mathrm{BC}$ were recorded under identical conditions, in the morning hours before a mutual preparation match. BC measurement by means of a bioimpedance method was carried out under standard conditions according to BIA guidelines (Kyle et al., 2004).

From the perspective of sports training periodization, the teams were at the end of a period of 7 weeks' preparation. Prior to ( 24 hours before) measurements, the participants did not take any medications, drugs (alcohol, caffeine, etc.) or pharmacological preparations which could influence the results of the measurement. The room temperature was kept between 20 and $24^{\circ} \mathrm{C}$ due to undesirable changes in water (Dittmar, 2003). Just before the measurement, the current body weight (BW) of the participants was read on an electronic digital scale (SECA 769, Hamburg, Germany) with a precision of $0.1 \mathrm{~kg}$, and the body height $(\mathrm{BH})$ of the participants in an upright position was measured with the precision of full $\mathrm{mm}$ by means of digital stadiometer (SECA 242, Hamburg, Germany).

The all body bioimpedance was determined with the phase sensitive whole body tetrapolar bioimpedance analyzer BIA $2000 \mathrm{M}$ device (Data Input $\mathrm{GmbH}$, Germany) which works on four frequencies (1, 5, 50 and $100 \mathrm{kHz}$ ) and is compatible with the NUTRI 4 software. The measurement was carried out in a lying position and participants' extremities were abducted. Four electrodes were placed on the proximal and dorsal surface of the right hand and right foot. The measurement itself took about $45 \mathrm{~s}$. The contact resistance between the electrode surface and the skin did not exceed $250 \mathrm{Ohms}$. Information about the measurement's reliability and the validity of this method in the general population has been published by Dittmar (2003). We were particularly interested in the amount of lean body mass (LBM), the percentage of fat mass (FM), the value of body cell mass (BCM) and its relative value (BCMrel) and extracellular mass (ECM) and their mutual ratio (ECM/ 
$\mathrm{BCM})$, the percentage of BCM in LBM (CQ), the phase angle $(\alpha)$, the basal metabolic rate (BMR), total body water (TBW) with a distinction between extracellular (ECW) and intracellular (ICW) water. Recalculations of individual, indirectly measurable parameters identifying the $\mathrm{BC}$ quality were based on the respective prediction equations (Data Input, 2004).

This study was approved by ethical committee of the Faculty of Physical Education and Sport, Charles University in Prague and measurements were performed according to the ethical standards of the Helsinki Declaration.

\section{Statistical analysis}

To compare measured parameters between both teams, a simple analysis of variance (One-way ANOVA) was used. To eliminate a null hypothesis about the equality of the examined parameters, we used the level of probability of $p<0.05$.

From the perspective of practical significance in the examination of differences between these groups, we used an index of effect size - ES (Cohen's $d$ ). The size of the differences was measured according to Thomas and Nelson (1996): $\mathrm{ES}>0.8$ (large), $\mathrm{ES}=0.5$ (moderate), ES $<0.2$ (small).

\section{RESULTS}

TBW in the screened sample was TBW $=40.15 \pm 2.68$. The total body water mean value in the screened teams was $\mathrm{TBW}=40.15 \pm 2.681$. The mean $\mathrm{ICW}$ value in all players was $23.14 \pm 0.801$. During the examination of ICW in individual teams we measured $\mathrm{T}_{\mathrm{ICW}}=$
$23.19 \pm 0.861$ (TABLE 2), which makes $57.77 \pm 2.04 \%$ of BW and $31.77 \pm 1.06 \%$ of the mean BW. In T2 the recorded value of ICW was $23.08 \pm 0.761(57.47 \pm 1.89 \%$ of BW and $32.51 \pm 1.07 \%$ of the mean BW). The extracellular water mean value in the screened samples was $17.00 \pm 1.941$, when $\mathrm{T} 1_{\mathrm{ECW}}=16.97 \pm 1.911(42.28 \pm 4.56 \%$ $\mathrm{z} \mathrm{BW})$ and in $\mathrm{T} 2_{\mathrm{ECW}}=17.06 \pm 2.101(42.48 \pm 5.23 \%$ $\mathrm{z} \mathrm{BW}_{\mathrm{TBW}}$ ).

The lean body mass mean value of all women players was $61.39 \pm 5.05 \mathrm{~kg}$. Neither statistical, nor effect size significance were proven in the difference between the teams $\left(p>0.05, \mathrm{ES}_{\mathrm{LBM}}=0.15\right)(\mathrm{TABLE} 2)$.

Distinguishing between ECM and BCM, a greater percentage of BCM was recorded. BCMrel was almost identical in both teams. ECM amounted in all players to $\mathrm{ECM}=25.21 \pm 2.36 \mathrm{~kg}$.

The ratio of $\mathrm{ECM} / \mathrm{BCM}$ for all players was $0.85 \pm 0.09$, and $\mathrm{T} 1_{\mathrm{ECM} / \mathrm{BCM}}=0.83 \pm 0.09$, which is in accordance with a high $a$ value $\left(\mathrm{T}_{\alpha}=6.62 \pm 0.64^{\circ}\right) . \mathrm{T} 2$ showed the mean value of ratio $\mathrm{T} 2_{\mathrm{ECM} / \mathrm{BCM}}=0.89 \pm 0.09$ with a phase angle value $\mathrm{T} 2_{\alpha}=6.28 \pm 0.54^{\circ}$ (for the whole screened sample the $\alpha$ was $6.47 \pm 0.61^{\circ}$ ). The difference in proportion between the examined groups was not significant (for ECM/BCM: $F=1.743 ; p=0.203$; for $\alpha: F=1.652 ; p=0.214)$. However, in terms of effect size we found moderate differences between the examined groups $\left(\mathrm{ES}_{\mathrm{ECM} / \mathrm{BCM}}=0.58: \mathrm{ES}_{\alpha}=0.58\right)$.

The BCM percentage in LBM in all players amounted to $\mathrm{CQ}=48.38 \pm 3.17 \%$. The FM mean percentage within the screened sample was of average proportion $\mathrm{FM}=15.57 \pm 3.13 \%$, and $\mathrm{T}_{\mathrm{FM}}=16.19 \pm 3.10 \%$ and in $\mathrm{T} 2$ the value was lower of $1.45 \%\left(\mathrm{~T} 2_{\mathrm{FM}}=14.74 \pm 3.15 \%\right.$; $F=1.107 ; p=0.306)$. The effect size showed moderate difference between the groups $\left(\mathrm{ES}_{\mathrm{FAT}}=0.46\right)$.

TABLE 2

Body composition profile in the screened teams and their statistical comparison (Mean Standard Deviation)

\begin{tabular}{|c|c|c|c|c|c|c|}
\hline \multirow{2}{*}{ Parameter } & Team 1 & Team 2 & \multirow{2}{*}{$\mathbf{F}_{\mathbf{( 1 , 2 0 )}}$} & \multirow{2}{*}{ Sig. } & \multicolumn{2}{|c|}{ Effect size } \\
\cline { 2 - 3 } & Mean (SD) & Mean (SD) & & ES value & ES level \\
\hline TBW $(1)$ & $40.14(2.67)$ & $40.16(2.85)$ & 0.00 & 0.99 & 0.01 & small \\
\hline LBM $(\mathrm{kg})$ & $61.03(4.22)$ & $61.87(6.24)$ & 0.13 & 0.72 & 0.15 & small \\
\hline$\alpha\left(^{\circ}\right)$ & $6.62(0.64)$ & $6.28(0.54)$ & 1.65 & 0.21 & 0.58 & moderate \\
\hline ECM $(\mathrm{kg})$ & $24.83(2.03)$ & $25.72(2.79)$ & 0.72 & 0.41 & 0.36 & moderate \\
\hline BCM $(\mathrm{kg})$ & $30.02(2.69)$ & $29.12(1.87)$ & 0.73 & 0.40 & 0.40 & moderate \\
\hline ECM/BCM & $0.83(0.09)$ & $0.89(0.09)$ & 1.74 & 0.20 & 0.58 & moderate \\
\hline ECW $(1)$ & $16.97(1.91)$ & $17.06(2.10)$ & 0.01 & 0.92 & 0.04 & small \\
\hline ICW (1) & $23.19(0.86)$ & $23.08(0.76)$ & 0.10 & 0.76 & 0.14 & small \\
\hline FM $(\%)$ & $16.19(3.10)$ & $14.74(3.15)$ & 1.11 & 0.31 & 0.46 & moderate \\
\hline CQ $(\%)$ & $49.19(2.98)$ & $47.31(3.26)$ & 1.89 & 0.18 & 0.60 & moderate \\
\hline BCM & $0.41(0.04)$ & $0.41(0.02)$ & 0.04 & 0.85 & 0.09 & small \\
\hline
\end{tabular}

Legend: SD - standard deviation, TBW - total body water, LBM - lean body mass, $\alpha$ - phase angel, ECM - extracellular mass, BCM body cellular mass, ECM/BCM - ratio of extracellular mass to body cellular mass, ECW - extracellular water, ICW - intracellular water, BMR - basal metabolic rate, FM - fat mass, CQ - cell quote, BCMrel - body cellular mass per kilogram of body weight, *p < 0.05 , ES effect size: $>0.8$ (large) $=0.5$ (moderate),$<0.2$ (small) 


\section{DISCUSSION}

The level of the examined parameters measured by the multifrequency bioimpedance method testifies to the quality of BC in both teams. LBM, active mass with a low proportion of essential fat (Lohman, 1992) amounted in the examined samples to an almost identical value (TABLE 1). According to research sources (Bandyopadhyay, 2007) volleyball players show significantly higher LBM values than the non sporting population. This parameter, including all body tissues except for depot fat, is considered a major precondition for good performance in volleyball. A higher value of LBM provides a better predisposition for sport performance based on explosive activity. Melrose et al. (2007) speak of a close correlation of LBM recorded in young women volleyball players $(n=29$, average age $=14.30 \pm 1.37$ year) with isometric arm flexion strength $(r=0.90)$, isometric leg flexion strength $(r=0.62)$ and with the ball's velocity after a serve $(r=0.58)$. An important parameter of $\mathrm{BC}$ is $\mathrm{BCM}$ as a component of LBM, which is represented by the metabolically active aerobic cells of the skeletal muscles and the heart musculature, internal organs, bone tissue, blood cells and the central nervous system. According to Andreoli et al. (2003), the assessment of BCM belongs among the best predictors of muscular efficiency predicting sports performance. We recorded comparable values of BCM in both teams (TABLE 1). If we expressed BCM as a percentage of the proportion of cells inside LBM and thus as an indicator of an individual's state of nutrition and the training load of a particular athlete, we would receive another parameter characterizing the LBM (CQ) quality. This parameter indicates a high quality of LBM in players, when the mean value of both teams $(\mathrm{CQ}=48.38 \pm 3.17 \%)$ reached almost the limit of the recommended $50 \%$ of BCM proportion in LBM (Data Input, 2004). For top performance athletes, BCM may grow to up to $60 \%$ of LBM (Dörhöfer \& Pirlich, 2007). However, this criterion is stated generally, not specifically for volleyball players (women players). Malá et al. (2010) reported the value CQ $=54.5 \%$ in Slovak national women volleyball players.

In comparing BCM and ECM in both samples, the mean BCM proportion was higher than that of ECM. Both teams therefore possessed a high mean proportion of BCM. The amount of BCM is conditioned both genetically (constitutional type) and by age, and on the orientation of the training (above all, the type of activity in terms of its energy demands) which the players undergo. Top performance women volleyball players whose training process includes high quality physical fitness preparation since their youth should possess high $\mathrm{BCM}$ values as compared to the ordinary population.

In practice the importance of the ratio of both components, $\mathrm{ECM} / \mathrm{BCM}$, is stressed as a criterion for the assessment of a predisposition for muscular activity. For athletes, its values range between 0.70-1.00 depending on the type of sport (Data Input, 2004). A drop in $\mathrm{ECM} / \mathrm{BCM}$ in most cases indicates an improved BC level, its decrease, however, may also be caused by a loss of water in the extracellular space, e.g. due to an insufficient drinking regime in a period of strain, or after a period of strain. The screened teams showed the mean value of $\mathrm{ECM} / \mathrm{BCM}=0.86 \pm 0.09$, which is similar to the value reported by Malá et al. (2010) in the Slovak women's national team $(0.84 \pm 0.08)$. The difference in $\mathrm{ECM} / \mathrm{BCM}$ values between the examined teams was not statistically significant, but from the effect size point of view a moderate difference was recorded. For most players (0.73-0.85), these values indicate an excellent predisposition for muscular activity and, therefore, for physical performance, which is one of the preconditions for the individual playing performance of a player.

The BCM value also regulates the energy consumption of the organism specifying its energy demands. BCM and FFM are closely linked to the BMR (Wang et al., 2007). These data may help in the modification of the dietary regime, the planning of training and other components considered by the coach while increasing the training load of the players. The mean BMR recorded in the screened sample was $1,552.38 \pm 73.95 \mathrm{kcal}$, but difference between the teams was not significant.

As for the fat component, the opinions in the professional literature concerning its optimal percentage vary. Essential fat, which is a component part of organs (marrow, heart, lungs, kidney, brain, etc.) is essential for the normal functioning of the organism. Subcutaneous fat provides for the protection of organs and their insulation, however, an excessive amount of it limits the quality of the motor performance of players (the height of a jump, agility, coordination, etc.). In our study, we did not find any significant differences in fat mass (FM) between the measured groups. However, effect size was moderate between the groups. A proportion of the inactive component in the examined players is in accordance with the literature where Lohman (1992) suggests BF values for sporting women ranging between $12-16 \%$ depending on the type of sport. Malá et al. (2010) reported a value of $13.72 \pm 2,4 \%$ by means of bioimpedance analysis (BIA 2000M) in the Slovak national players who participated in the European Championship of 2009 $(\mathrm{n}=12$, age $=24.0 \pm 1.1$ years, $\mathrm{BH}=179.4 \pm 7.3 \mathrm{~cm}$, $\mathrm{BW}=67.8 \pm 5.9 \mathrm{~kg}$ ).

Fleck et al. (1985) present a significantly lower value FM $(p<0.01)$ measured by the hydrodensitometry method in the USA Olympic National team $(11.7 \pm 3.7 \%)$ in comparison with a university team $(18.3 \pm 3.4 \%)$. Melrose et al. (2007) suggest a mean FM value of $21.0 \pm 5.5 \%$ measured by the bioimpedance method (Omron) in registered women volleyball players $(n=13$, age $15.5 \pm 0.6$ years, $B H=70.0 \pm 7.0 \mathrm{~cm}$, 
$\mathrm{BW}=62.8 \pm 6.6 \mathrm{~kg}$ ). Tsunawake et al. (2003) measured a value of $18.4 \pm 3.3 \%$ by the hydrodensitometry method in the players of an inter high school league $(\mathrm{n}=12$, age $=17.4$ years, $\mathrm{BH}=168.7 \pm 5.9 \mathrm{~cm}, \mathrm{BW}=$ $59.7 \pm 5.7 \mathrm{~kg})$. Some sources provide values above even a level of 20\% (Almeida \& Soares, 2003; Ferris et al., 1995; Filaire, Duché, \& Lac, 1998; Frasson et al., 2009; Kreger \& Brown, 2008; Malousaris et al., 2008; Nichols, Sanborn, Bonnick, Gench, \& DiMarco, 1995), the proportion of FM therefore varies depending not only on the type and level of motor activity but on the methods used and other factors, as well. Selected results of FM in women volleyball players are illustrated in Fig. 1.

A low percentage of FM in the screened teams apparently relates to the fact that players of both teams have the status of professional players, which means regular monitoring of nutrition regime and $\mathrm{BW}$.

The examined teams showed almost an identical proportion of TBW. This parameter is very important for the monitoring of performance because states accompanying changes in $\mathrm{BC}$ are often only connected with an unfavorable decrease in TBW (e.g. an insufficient

Fig. 1

Proportion of fat mass in the chosen womens' volleyball teams

Fat Mass (\%)

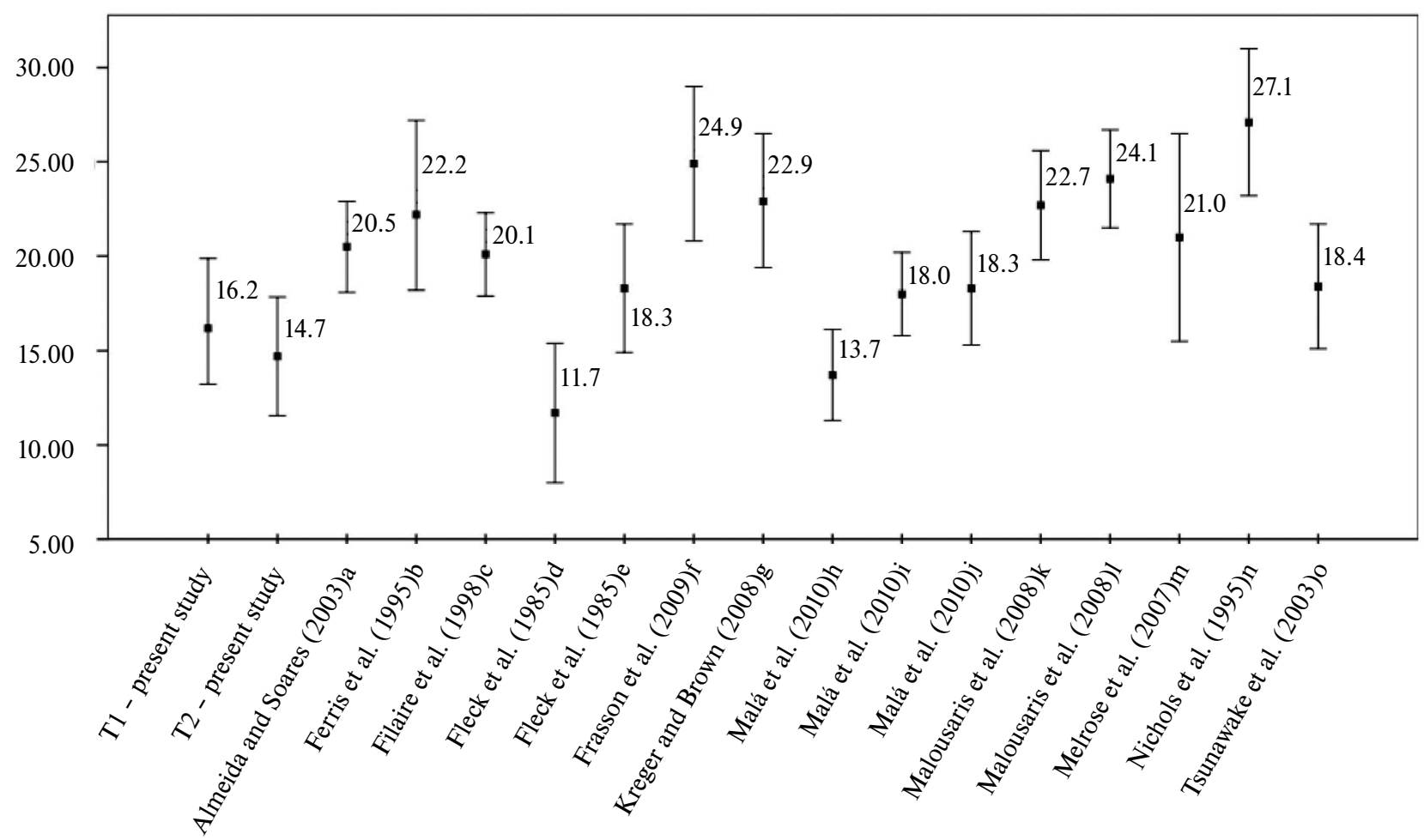

Source

Legend (number of participants, age, performance level, methods of measurement):
(a) $-\mathrm{n}=25,16.0$, high performance, skin folds
(b) $-\mathrm{n}=13,19.5$, NCAA division, hydrodensitometry
(c) $-\mathrm{n}=7, \quad 24.6$, top-performance, not stated
(d) $-\mathrm{n}=12,23.5$, national players of USA, hydrodensitometry
(e) $-\mathrm{n}=14,21.5$, university team USA, hydrodensitometry
(f) $-\mathrm{n}=22,15.8$, not stated, bioimpedance
(g) $-\mathrm{n}=8, \quad 19.1$, university women players, hydrodensitometry
(h) $-\mathrm{n}=12,24.0$, national players of Slovakia, bioimpedance
(i) $-\mathrm{n}=12,18.0$, national players of Slovakia U19, bioimpedance
(j) $-\mathrm{n}=14,16.6$, national players of Slovakia (U17), bioimpedance
(k) $-\mathrm{n}=79,25.7$, I. Greek league, skin folds
(1) $-\mathrm{n}=84,22.0$, II. Greek league, skin folds
(m) $-\mathrm{n}=15,15.5$, high performance, bioimpedance
(n) $-\mathrm{n}=13,19.4$, university women players, DEXA
(o) $-\mathrm{n}=12, \quad 17.4$, university league, hydrodensitometry 
drinking regime during the training process or regeneration period). During the changes, however, apart from the TBW volume, the distribution of its parts and mainly its intracellular component, must also be monitored.

For $\alpha$, which provides us with information on the integrity of cells and allows us to analyze their condition (Dörhöfer \& Pirlich, 2007), the standard value is considered to range between $5-7^{\circ}$ (Data Input, 2004). The recorded values indicate a high cell quality in both teams, which should also be connected with a higher percentage of intracellular volume and, in the final account, of BCM as compared to the general population. In individual assessment, the highest $\alpha$ values were recorded in the T1 team $\left(6.8-7.3^{\circ}\right)$.

Some limitations of our study should be considered. The Multifrequency BIA measurement uses standardized formulas for the calculation of LBM with the assumption that the water content of LBM is 73\% (Mika, Herpetz-Dahlmann, Heer, \& Holtkamp, 2004).

Particularly in women athletes, this assumption can be influenced by insufficient hydration, overloading, inappropriate nutrition, menstruation, etc. In this case, underestimation or overestimation of LBM in the women athlete's body may appear. The next limit of the study is the absence of regressive equations for the particular target group (current elite women's volleyball).

A more appropriate method for the measurement of body FM is dual energy X-ray absorptiometry, but this method is usable only under laboratory conditions. In our case, we had to carry out the measurements under field conditions due to organizational reasons. The benefit of this study is in data gained from professional women volleyball players, which may help to approximate standards for elite volleyball. In the literature, the terms "elite volleyball" and "top performance volleyball" often refer to players at a lower performance level.

\section{CONCLUSIONS}

The article presents a $\mathrm{BC}$ profile and a comparison between the top-performance women volleyball players of two teams - participants in the highest European League. The multi-frequency whole body bioimpedance method detected the values of individual parameters, identifying the $\mathrm{BC}$ of women volleyball players, at a level corresponding to top performance sport as compared to high performance sport or the general population. The observed parameters between both screened samples were not statistically significant. However, effect size revealed moderate differences for other parameters ( $\alpha$, ECM, BCM, ECM/BCM, BMR, FM and CQ). It appears that, in the case of top level volleyball, the proportion of FM should not be higher than 18\% (an appropriate proportion is lower than $16 \%$ ). The ECM/ BCM index should not climb above 0.85 . In assess- ment of the "success" of the team in terms of playing performance, T2 was obviously more successful in the Champions League than team T1. Demands on physical predisposition (including BC) for professional volleyball are increasingly higher, because its weaknesses must be compensated for by other qualities (experience, the ability to anticipate, and volleyball intelligence). The highest level of sport performance may be achieved only by the synergic influence of all partial components (factors of sport performance). However, BC must be monitored not only selectively, but continuously. This type of information may allow the coach or the players themselves to identify their own changes in $\mathrm{BC}$, when measured regularly (the state of internal preparedness/quality), and the reaction of the organism to the adaptation used, or non adaptation stimuli in periodized sports training, during convalescence after an injury or adequate supplementation. The BC characteristics of elite women volleyball players can serve as standards for other athletes attempting to achieve an international level in terms of BC parameters.

\section{ACKNOWLEDGEMENTS}

This project was supported by MSM 0021620864; GAČR 407/11/P784.

\section{REFERENCES}

Almeida, T. A., \& Soares, E. A. (2003) Nutritional and anthropometric profile of adolescent volleyball athletes. Revista Brasileira de Medicina do Esporte, 9(4), 198-203.

Anderson, D. E. (2010). The impact of feedback on dietary intake and body composition of college women volleyball players over a competitive season. Journal of Strength and Conditioning Research, 24(8), 2220-2226.

Arden, N. K., \& Spector, T. D. (1997). Genetic influences on muscle strength, lean body mass, and bone mineral density: a twin study. Journal of Bone and Mineral Research, 12(12), 2076-2081.

Andreoli, A., Melchiorri, G., Brozzi, M., Di Marco, A., Volpe, S. L., Garofano, P., Di Daniele, N., \& De Lorenzo, A. (2003). Effect of different sports on body cell mass in highly trained athletes. Acta Diabetologica, 40, 122-125.

Bandyopadhyay, A. (2007). Anthropometry and body composition in soccer and volleyball players in West Bengal, India. Journal of Physical Anthropology, 26(4), 501-505.

Bayios, I. A., Bergeles, N. K., Apostolidis, N. G., Noutsos, K. S., \& Koskolou, M. D. (2006). Anthropometric, body composition and somatotype differ- 
ences of Greek elite female basketball, volleyball and handball players. The Journal of Sports Medicine and Physical Fitness, 46(2), 271-280.

Carbuhn, A. F., Fernandez, T. E., Bragg, A. F., Green, J. S., \& Crouse, S. F. (2010). Sport and training influence bone and body composition in women collegiate athletes. Journal of Strength and Conditioning Research, 24(7), 1710-1717.

Data Input. (2004). Manual Nutri 4 - Multifrequency Software for the determination of body water, body composition and nutritional status. Instructions for use, Company DataInput GmBH, Trakehner Strasse 5, 60487, Frankfurt am Main, Germany.

Dittmar, M. (2003). Reliability and variability of bioimpedance measures in normal adults: Effects of age, gender, and body mass. American Journal of Physical Anthropology, 122(4), 361-370.

Dostálová, I., Riegerová, J., \& Přidalová, M. (2007). Body composition of young volleyball players [Abstract]. Acta Universitatis Palackianae Olomucensis. Gymnica, 37(2), 42.

Dörhöfer, R. P., \& Pirlich, M. (2007). Das BIA - Kompendium, III. Ausgabe. Data Input GmbH, Darmstadt.

Ferris, D. P., Signorile, J. F., \& Caruso, J. F. (1995). The relationship between physical and physiological variables and volleyball spiking velocity. Journal of Strength and Conditioning Research, 9(1), 32-36.

Filaire, E., Duché, P., \& Lac, G. (1998). Effect of training for two ball games on the saliva response of adrenocortical hormones to exercise in elite sportswomen. European Journal of Applied Physiology and Occupational Physiology, 77(5), 452-456.

Fleck, S. J., Case, S., Puhl, J., \& Van Handle, P. (1985). Physical and physiological characteristics of elite women volleyball players. Canadian Journal of Applied Sport Sciences, 10(3), 122-126.

Frasson, V. B., Diefenthaeler, F., \& Vaz, M. A. (2009). Comparative study of anthropometric variables in female classical ballet dancers, volleyball players and physical active subjects. Revista Brasileira de Cineantropometria \& Desempenho Humano, 11(1), $8-13$.

Gualdi-Russo, E., \& Zaccagni, L. (2001). Somatotype, role and performance in elite volleyball players. The Journal of Sports Medicine and Physical Fitness, 41(2), 256-262.

Häkkinen, K. (1993). Changes in physical fitness profile in female volleyball players during the competitive season. The Journal of Sports Medicine and Physical Fitness, 33(3), 306-316.

Kreger, K. J., \& Brown, D. D. (2008). Seasonal physical and body composition changes in division I collegiate volleyball players. Medicine \& Science in Sport \& Exercise, 40(5), 392.
Kyle, U. G., Bosaeus, I., De Lorenzo, A. D., Deurenberg, P., Elia, M., Manuel Gomez, J., et al. (2004). Bioelectrical impedance analysis - part II: Utilization in clinical practice. Clinical Nutrition, 23(6), 1430-1453.

Lohman, T. G. (1992). Advances in body composition assessment. Champaign, IL: Human Kinetics.

Malá, L., Malý, T., Zahálka, F., \& Bunc, V. (2010). The profile and comparison of body composition of elite female volleyball players. Kinesiology, 42(1), 90-97.

Malousaris, G. G., Bergeles, N. K., Barzouka, K. G., Bayios, I. A., Nassis, G. P., \& Koskolou, M. D. (2008). Somatotype, size and body composition of competitive female volleyball players. Journal of Science and Medicine in Sport, 11(3), 337-344.

Melrose, D. R., Spaniol, F. J., \& Bohling, M. E. (2007). Physiological and performance characteristic of adolescent club volleyball players. Journal of Strength and Conditioning Research, 21(2), 481-486.

Mika, C., Herpertz-Dahlmann, B., Heer, M., \& Holtkamp, K. (2004). Improvement of nutritional status as assessed by multifrequency BIA during 15 weeks of refeeding in adolescent girls with anorexia nervosa. The Journal of Nutrition, 134(11), 3026-3030.

Nichols, D. L., Sanborn, C. F., Bonnick, S. L., Gench, B., \& Di Marco, N. (1995). Relationship of regional body composition to bone mineral density in college females. Medicine and Science in Sport and Excercise, 27(2), 178-182.

Riegerová, J., \& Ryšavý, J. (2001). Somatodiagnostic of female, secondary school age volleyball players. Acta Universitatis Palackianae Olomucensis. Gymnica, 31(1), 37-42.

Reilly, T. (1996). Fitness assessment. In T. Reilly (Ed.), Science and Soccer (pp. 25-50). London: E. \& F. Spon.

Thomas, J. R., \& Nelson, J. K. (1999). Research methods in psychical activity. Champaign, IL: Human Kinetics.

Tsunawake, N., Tahara, Y., Moji, K., Muraki, S., Minowa, K., \& Zukawa, K. (2003). Body composition and physical fitness of female volleyball and basketball players of the Japan inter high school championship teams. Journal of Physiological Anthropology and Applied Human Science, 22(4), 195-201.

Vařeková, R., Vařeka, I., Valenta, M., Přidalová, M., \& Burianová, K. (2006). Observation of the dispositional anthropometrical factors in footballers at the age of juvenis. In Z. Borysiuk (Ed.), $5^{\text {th }}$ International conference Movement and Health (pp. 184-187). Opole: Opole University of Technology.

Wang, Z., Heshka, S., Wang, J., Gallagher, D., Deurenberg, P., Chen, Z., \& Heymsfield, S. B. (2007). Metabolically active portion of fat free mass: A cellular body composition level modeling analysis. American Journal of Physiology, Endocrinology and Metabolism, 292(1), 49-53. 


\section{SROVNÁNÍ TĚLESNÉHO SLOŽENÍ DVOU ŠPIČKOVÝCH ŽENSKÝCH VOLEJBALOVÝCH TÝMŮ}

(Souhrn anglického textu)

VÝCHODISKA: Ve sportu a zvláště ve vrcholovém sportu může průběžné sledování tělesného složení (body composition - BC) přinést pozitivní zhodnocení efektu tréninkového procesu. Úroveň tělesného složení (BC) je proto považována za jednu z komponent tělesné zdatnosti sportovců. Výzkumné studie zabývající se tělesným složením u volejbalistek jsou často zaměřeny na nižší výkonnostní úrovně ve srovnání s předloženou studií. Problémem v oblasti porovnávání výsledků je také odlišnost použité metodiky při stanovení tělesného složení.

CÍLE: Cílem studie je popis profilu tělesného složení (BC) hráček volejbalu nejvyšší úrovně a ověření rozdílů vybraných parametrů $\mathrm{BC}$ mezi sledovanými skupinami. Výzkumná skupina se skládala $\mathrm{z}$ hráček dvou týmů, které se účastnily Evropské ligy mistryn̆ (T1, n = 12; T2, $\mathrm{n}=9)$.

METODIKA: Pomocí měření multifrekvenční bioimpedance jsme sledovali tukuprostou hmotu (LBM), tukovou hmotu (FM), tělesnou buněčnou hmotu (BCM), relativní BCM (BCMrel), mimobuněčnou hmotu (ECM) a jejich poměr (ECM/BCM), percentuální zastoupení BCM v LBM (CQ), fázový úhel $(\alpha)$, basální metabolismus (BMR), celkovou tělesnou vodu (TBW) spolu $\mathrm{s}$ rozdílem mezi mimobuněčnou ( $\mathrm{ECW})$ a buněčnou (ICW) vodou. Pro srovnání rozdílů mezi sledovanými týmy jsme použili One-way ANOVA a velikost efektu jsme posuzovali pomocí indexu Cohenova $d$.

VÝSLEDKY: Rozdíly sledovaných parametrů tělesného složení ve zkoumaném vzorku nebyly signifikantní $(p>0.05)$. Věcná významnost prokázala středně veliký účinek rozdílu pro některé parametry $(\alpha, \mathrm{ECM}, \mathrm{BCM}$, ECM/BCM, BMR, FM a CQ). Tuková hmota byla u sledovaných hráček procentuálně nižší ve srovnání s hráčkami ve většině ostatních studií. Relativně vyšší hodnoty parametrů TBW, LBM a ECM/BCM v kategorii ženských hráček volejbalu ukazují dobrou výkonnostní úroveň.

ZÁVĚRY: Profil tělesného složení prokázal vhodné predispozice sledované skupiny pro vrcholový volejbal. Měřené parametry BC korespondují s hodnotami hráček vrcholové úrovně a jsou na lepší úrovni, než jsou hodnoty běžné populace. Námi získané hodnoty parametru BC u hráček volejbalu vrcholové úrovně mohou sloužit jako standardy pro ostatní sportovce nejvyšší výkonnostní úrovně.

Klíčová slova: tělesná zdatnost, tělesná kondice, ženy, tělesný tuk, vrcholový sport.

\section{PaedDr. Tomáš Malý, Ph.D.}

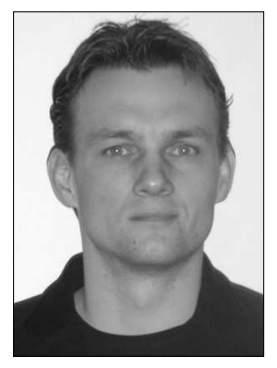

Charles University

Faculty of Physical Education and Sport Sport Research Centre

José Martího 31

16252 Praha 6

Czech Republic

\section{Education and previous work experience}

Since 2007 - researcher, Sport Research Centre, Faculty of Physical Education and Sport, Charles University in Prague.

2003-2009 - degree Ph.D., postgraduate study at FPE and Sport, Charles University in Prague in the field of Kinanthropology.

2003-2007 - assistant at Faculty of Sports, Prešov University in Prešov.

2003 - degree PaedDr. at Faculty of Humanities and Natural Sciences, Prešov University, Slovakia.

1998-2003 - graduate of master's degree program at Faculty of Humanities and Natural Sciences, Prešov University, Slovakia.

\section{First-line publications}

Malý, T., Bunc, V., Malá, L., \& Zahálka, F. (2011). The effect of ten months intervention on postural stability of individuals with health impairment. International Journal of Fitness, 7(1), 1-12.

Malý, T., Zahálka, F., \& Malá, L. (2010). Isokinetic strength, ipsilateral and bilateral ratio of peak muscle torque in knee flexors and extensors in elite young soccer players. Acta Kinesiologica, 4(2), 14-23.

Malý, T., Zahálka, F., \& Malá, L. (2010). Body composition profile of elite women volleyball players. International Journal of Volleyball Research, 10(1), 14-19.

Malý, T., Zahálka, F., Hráský, P., Čada, M., Dovalil, J., \& Malá, L. (2009). The comparison between the speed of the serve and the chosen biomechanical parameters of the serve in the training and match conditions in the women volleyball. Antropomotoryka, 19(45), 17-24. 